Journal of Southeast Asian

\title{
Gender, Culture, and the Educational Choices of Second Generation Hmong American Girls
}

Bao Lo

California State University, Stanislaus, ms.baolo@gmail.com

Follow this and additional works at: https://docs.lib.purdue.edu/jsaaea

Part of the Asian American Studies Commons, Ethnic Studies Commons, and the Other Sociology Commons

\section{Recommended Citation}

Lo, Bao (2017) "Gender, Culture, and the Educational Choices of Second Generation Hmong American Girls," Journal of Southeast Asian American Education and Advancement. Vol. 12 : Iss. 1, Article 4. DOI: 10.7771/2153-8999.1149

Available at: https://docs.lib.purdue.edu/jsaaea/vol12/iss1/4

This document has been made available through Purdue e-Pubs, a service of the Purdue University Libraries. Please contact epubs@purdue.edu for additional information.

This is an Open Access journal. This means that it uses a funding model that does not charge readers or their institutions for access. Readers may freely read, download, copy, distribute, print, search, or link to the full texts of articles. This journal is covered under the CC BY-NC-ND license. 


\title{
USA AEA Journal of Southeast Asian American
Education and Advancement
}

Vol. 12 Iss. 1 (2017)

WWW.JSAAEA.org

\section{Gender, Culture, and the Educational Choices of Second Generation Hmong American Girls}

\author{
Bao Lo \\ California State University, Stanislaus
}

\begin{abstract}
Research on the educational achievement of racialized minorities and immigrants have largely discussed culture as either a deficit or an advantage for academic success. This paper explores gender differences in educational achievement and how the educational choices of second-generation Hmong American girls are impacted by racially constructed gender norms. In response to hegemonic and subordinated femininities, second-generation Hmong American girls pursue education to enter mainstream America and reject Asian ethnic culture and femininity. Gender equality is normalized and equated with White femininity and American mainstream culture while Asian femininity and ethnic culture is constructed and subordinated as "other." This research complicates the salience of culture in scholarship on minority student achievement and considers how the educational choices of second-generation Hmong American girls draw ideologically on a racial discourse that reinforces White dominance.
\end{abstract}

Keywords: Gender, culture, Hmong Americans, second-generation incorporation, education

\footnotetext{
@)

SDMERIEHISRESERNEDReaders are free to copy, display, and distribute this article, as long as the work is attributed to the author(s) and the Journal of Southeast Asian American Education \& Advancement, it is distributed for non-commercial purposes only, and no alteration or transformation is made in the work. More details of this Creative Commons license are available at http://creativecommons.org/licenses/by-nc-nd/3.0/. All other uses must be approved by the author(s) or JSAAEA .

Journal of Southeast Asian American Education \& Advancement, Vol. 12. Iss. 1. (2017) ISSN: 2153-8999
} 


\section{Introduction}

The girls are more motivated and doing much better. Even in college, the girls are graduating more than the guys. In five more years, I would say that the females will dominate the males in education. We are culturally shifting in terms of gender differences in academic performance and this will affect the families. Usually the male dominates in the family and goes to work. With the gender difference, now the female will go to work and the male will take care of the family (Mr. Lor, Hmong Teacher).

Mr. Lor's statement attests to important gender differences in academic achievement among second-generation Hmong Americans, who constitute ${ }^{1}$ a growing segment of the Hmong American population that is largely U.S. born and young. Members of the Hmong community also speculate that the number of women in higher education has significantly increased and has quite possibly surpassed the number of men since the 1980s and 1990s, when more Hmong men were achieving a higher education (Vang, 2004). Prior to their arrival in the U.S., very few Hmong women received a formal education (Cha, 2013). However, many Hmong parents now support both genders to obtain education due to changing gender roles and economic forces (Lee, 2007). As educational opportunities present themselves to Hmong girls in the U.S., Hmong girls have taken up these opportunities to pursue higher education (Lee, 1997, 2005; Ngo, 2002).

Mr. Lor's statement also suggests that as more girls are academically outperforming the boys, the family structure and social organization of Hmong Americans will be altered. Education therefore plays an important role in shaping gender norms and Hmong culture. For instance, Lee (1997) showed how Hmong women postponed marriage and decided on smaller families in their pursuit of higher education. Thus, educational attainment among Hmong American women reflects the changes and fluidity of Hmong culture. Hmong culture is dynamic and in a constant process of being created and re-created as shown through the agency of Hmong American women (Lee, 1997; Ngo, 2002; Vang et al., 2016).

Ethnic cultures are not static as migration and the settlement process have shifted gender roles and ideologies within patriarchal societies, particularly as women gain greater independence and equality outside the home (Hondagneu-Sotelo, 1994; Kibria, 1993; Menjivar, 2000; Pessar, 1999). For instance, research on the resettlement experiences and acculturation of Hmong refugees reveal how Hmong women's achievement of greater equality and independence as more women gain opportunities in education, the workforce, and leadership roles has disrupted the Hmong social organization and challenged gender norms and ideologies (Donnelly, 1994; Moua \& Riggs, 2012; Vang, 2008). Donnelly (1994) showed how Hmong women altered gender roles by participating as the economic providers of the household. In households where the women were employed, the men felt a loss of prestige, self-esteem and authority.

As Hmong women adopt more egalitarian gender roles and ideologies from American mainstream culture, they make choices that challenge and change gender norms and Hmong culture. For instance, Lee (2005) found that Hmong girls perceived gender equality through education to negotiate the gender norms of Hmong culture. Similarly, Ngo (2002) shows how Hmong women use early marriage to challenge gender norms that provide them with social restrictions. The work of these scholars provides more nuanced interpretations of agency, adaptation, and cultural negotiation of gender norms by Hmong American women (Keown-Bomar \& Vang, 2016). These studies also challenge the construction of Hmong culture as monolithic, which has been largely depicted as culturally different, deficient and lacking against a modern 
White middle class mainstream (Donnelly, 1994; Faderman, 1998; Fadiman, 1997; Mote, 2004; Trueba, Jacobs, \& Kirton, 1990; Walker-Moffat; 1995).

Although studies acknowledge Hmong culture as fluid and changing and that Hmong American women are active participants of cultural change, more discussion is needed regarding discourse and ideologies that impact the self-perceptions and choices of Hmong American girls such as education (Pyke \& Johnson, 2003). Lee (2005) exposed the impact and normalization of whiteness in the experiences of Hmong American students. She revealed that teenage Hmong girls constructed their femininity in response to popular images of the American family that largely informed their ideas about gender relations at home and school. In turn, they perceived and equated greater freedom and gender equality with mainstream American families and culture.

In my research, the majority of second-generation Hmong American girls equated gender egalitarianism with White femininity and mainstream American culture. In response, they pursued education to obtain gender equality and rejected Asian ethnic culture and femininity, which they perceived as deficient or lacking. Their perception and glorification of gender equality and success as White middle-class America can be explicated by the analytical concepts of hegemonic and subordinated femininities (Pyke \& Johnson, 2003). These conceptual tools reveal the interlocking systems of oppression that reproduce inequality and internalized oppression, which is useful for explaining how second-generation Hmong girls make sense of and respond to messages about gender norms in their ethnic culture and from American mainstream. This theoretical frame accounts for how second-generation Hmong American girls' perception of gender is seen through a racialized lens. For instance, gender equality is normalized and equated with White femininity and American mainstream culture while Asian femininity and ethnic culture is constructed as lacking and deficient.

Studies have illustrated the agency of Hmong American women to transform culture through their educational choices (Lee, 1997; Ngo, 2002). However, there is a compelling need to explore the largely accepted and adopted White standards of gender among second-generation Hmong Americans that impact their educational choices. Moreover, scholarship on minority student achievement continues to employ culture as an analytic lens to explain differences in educational experiences and opportunities of racialized minorities and immigrants, such as Hmong Americans (Caplan, Choy, \& Whitmore, 1991; Rutledge, 1992; Trueba, Jacobs, \& Kirton, 1990; Walker-Moffat; 1995; Zhou \& Bankston, 1998; Zhou \& Lee, 2015). The prominent use of culture to explain opportunities and outcomes leads to victim blaming, while maintaining whiteness as the norm of success. This framing of culture is problematic and insufficient to explain the findings from my research. This article builds upon this scholarship and is guided by two interrelated questions: a) How do second-generation Hmong American girls interpret and make sense of gender norms in Hmong culture and mainstream America? b) How do they respond?

\section{Theoretical Background}

This paper is driven by an interest to better describe and explain gender norms in immigrant cultures and complicate the prominence of culture in minority student achievement and immigrant incorporation. In this section, I discuss useful conceptual tools that are important for making sense of the cultural dynamics of educational achievement among second-generation Hmong American girls. 


\section{Normalizing Whiteness and Assimilation}

Research on minority student achievement treat culture as a deficiency or an advantage for academic success. Studies on Southeast Asian American education attribute academic success to cultural values (Caplan, et al., 1991; Rutledge, 1992; Walker-Moffat; 1995; Zhou \& Bankston, 1998). These studies emerged during the 1980s to praise the newest group of Asian immigrants, particularly Southeast Asian refugee students who were mainly Vietnamese, as the exemplary immigrant minorities. For instance, Caplan et al. (1991) explained the success of Southeast Asian students as a result of their values of hard work and education. Furthermore, Rutledge (1992) expressed how education has always been extremely important to the Vietnamese since it brings high honor and value to families. Despite the transition to a "strange" system, Vietnamese children have successfully transferred over these values to achieve in American classrooms. These studies used cultural differences to account for disparities of educational achievement among immigrants and minorities, and have allowed little room for discussion of any barriers these immigrants might have faced due to race, class, or gender. The attentiveness to culture in explaining the integration of Vietnamese refugees also masks the differential patterns of adaptation among members of this group. For instance, the low educational attainment of Hmong Americans challenges the perception of Asian Americans as the model minority (Xiong, 2012).

Similarly, research on the incorporation of racialized immigrants emphasizes culture in the form of ethnic distinctiveness or attachment to the immigrant culture as an advantage for educational success and economic integration into American society (Gibson, 1988; Kibria, 1993; Portes \& Rumbaut, 2001; Zhou \& Bankston, 1998; Zhou \& Lee, 2015). These scholars offer an immigrant working-class model of assimilation, segmented assimilation theory, that suggest an immigrant advantage through attachment to the immigrant culture or ethnic distinctiveness provides working-class, poor immigrants and their children the best chances for upward mobility under economic constraints and racism. ${ }^{2}$ For instance, Zhou and Bankston (1998) found in their study with Vietnamese youth that social control or protection provided by the immigrant culture, the parents, and the community produced positive outcomes such as educational attainment, particularly among the girls, as the culture was stricter with females. Similarly, Gibson (1988) showed that the traditional values enforced strict rules and boundaries to help protect and shield Sikh girls from engaging in risky behaviors. On the other hand, second-generation youth who adopt an "oppositional" youth culture resembling the urban underclass were more likely to assimilate downward into the urban underclass.

The research on minority student achievement and immigrant incorporation reveal the salience of culture in education. According to these studies, culture is constructed as deficient or advantageous for academic success. However, culture is also discursively constructed to racialize immigrant culture as successful and urban underclass culture as failure (Ngo \& Lee, 2007). The model minority discourse is therefore stabilized to racialize achievement as Asian American and failure as African American (Sue \& Okazaki, 1990; Zhou \& Bankston, 1998). Thus, immigrant culture is marked as Asian, perpetuating their foreignness, while the underclass is equated as Black, reinforcing their inferiority to Whites (Ancheta, 2010; Kim, 1999; Omi \& Winant, 2015).

The racial discourse in education scholarship normalizes mainstream American culture or White middle-class America as superior while subordinating minorities and immigrants as "other" (Lee, 2005; Pyke, 2000). As mainstream American culture or whiteness is maintained as successful, those that deviate from this norm are blamed for their own plight. Consequently, policy is enforced to ignore or punish groups that do not fit this norm. Moreover, the emphasis on 
assimilation or integration into mainstream American culture normalizes and upholds Western culture as superior.

Going beyond reductionist arguments of culture requires understanding the interlocking systems of oppression that reproduce inequalities (Collins \& Bilge, 2016; Pyke \& Johnson 2003). For instance, Pyke and Johnson (2003) illustrate how a relational construction of hegemonic (White) and subordinated (Asian) femininities result in internalized oppression and the reproduction of inequality. As White femininity and mainstream American culture are treated as egalitarian and hegemonic, Asian femininity and ethnic culture are viewed as lacking and deficient (Pyke \& Johnson, 2003). Normalizing whiteness thus constructs and reproduces the subordination of the other. The findings in their study show that Asian females treat Asian ethnic cultures as deficit and lacking while equating greater gender equality with mainstream American culture. Also, Pyke and Johnson assert that the Asian females' adoption of gender egalitarianism as White femininity and mainstream American culture show evidence of assimilation. They warn of the proassimilationist perspective of the White-dominated mainstream that constructs Asian ethnic cultures as static, monolithic sites of male dominance and female submissiveness.

In this article, I extend the research on minority student achievement and immigrant incorporation and explore the ways second-generation Hmong American girls make sense of and respond to gender norms through a racialized lens. I draw on Pyke and Johnson's (2003) conceptualization of hegemonic and subordinated femininities to explain how the girls equate gender egalitarianism with White femininity and mainstream American culture and reject and challenge gender norms of their ethnic culture through education.

\section{Research Background}

This article draws on data from a larger study on the assimilation of second generation Hmong Americans (Lo, 2013). This study contributes to the research on the second generation of contemporary immigrants or post 1965 immigrants, who are racially, ethnically diverse and come from varying educational backgrounds and skills. More specifically, my larger study explored whether second generation Hmong Americans followed the trajectories suggested by the segmented assimilation model and how human capital and ethnicity account for the incorporation of second generation Hmong Americans, as emphasized by the model. Thus, this larger study aimed to address the following: What are the assimilation pathways of second-generation Hmong Americans and how does human capital and ethnicity matter for their incorporation? Findings from the larger study revealed that second generation Hmong Americans follow the trajectories of the segmented assimilation model but the outcomes varied by gender. The findings showed that the girls have a more promising pathway than the boys. Also, the different experiences of the girls and boys within the home or immigrant life and in dominant society could not be fully explained by the theoretical concepts and explanation offered by the segmented assimilation model. The themes that emerged from the larger study centralize gender in the experiences of second generation Hmong Americans and guide the particular arguments and focus of this paper.

\section{Research Context}

The research took place in Sacramento, California from 2007-2009. As my research site, Sacramento is home to the third largest Hmong population (26,996), after Minneapolis-St. Paul, 
Minnesota $(64,422)$ and Fresno, California (31,771). Due to resettlement efforts and migration patterns, Hmong refugees were widely dispersed throughout the country (Loescher \& Scanlan, 1986; Reder, 1986; Strand \& Jones, 1985). Today, they are concentrated in cities such as Minneapolis-St. Paul, Minnesota and Fresno and Sacramento, California, making this group important in those places. ${ }^{3}$ Among Sacramento's Hmong population, 43\% are under the age of 18, which is relatively larger than Sacramento (25\%), California (25\%), and the total U.S. population $(24 \%)$ that are under the age of 18. Sacramento's young Hmong population reflects the growing segment of the total U.S. Hmong population of 260,073 persons (alone or in combination with another race) that is largely American-born (United States Census Bureau, 2010).

In 2002, Time magazine labeled Sacramento as the most racially/ethnically integrated major city in America (Stodghill \& Bower, 2002). At the time of the study, the racial makeup of the city was 54\% White, 18\% Hispanic, 9\% African American, 2\% American Indian, 13\% Asian and Pacific Islander, and 4\% from other races. Hmong Americans constitute the fourth largest Asian American subgroup. In terms of education, Asian Americans do better than the general population. Among Asian Americans of age 25 or older, 38\% have a bachelor's degree or higher, which is slightly higher than Sacramento (30\%) and California (30\%). The national average is $28 \%$. However, there exists educational disparity among Asian Americans. For instance, only 14\% of Hmong Americans and 16\% of Pacific Islanders have received a bachelor's degree or higher. In contrast, Vietnamese (31\%), Asian Indians (49\%) Chinese (43\%), Filipino (40\%), and Japanese Americans (47\%) have received a bachelor's degree or higher (United States Census Bureau, 2009).

The lack of formal education due to limited educational opportunities in Laos accounts for the low educational attainment for Hmong Americans (Chiang, Fisher, Collins, \& Ting, 2015). Before their arrival to the U.S., many Hmong refugees had no formal education (Yang, 2013). Despite these challenges, there is an upward trend of educational attainment for Hmong Americans. For instance, Xiong (2012) explains that throughout the 1970s, 1980s, and 1990s, the majority of Hmong Americans had less than a high school education. The percentage of Hmong Americans age 25 years or older and hold a bachelor's degree or higher increased from 4.9 percent in 1990 to 7.4 percent in 2000. By 2010, it nearly doubled to 14.5 percent.

The difference in educational levels among Asian Americans pose many challenges for the Asian American community as well as the larger Sacramento community, especially since Asian Americans make up a significant portion of the city's population. This calls attention to the needs of the most disadvantaged groups within the Asian American community, such as Hmong Americans.

\section{Data Collection and Analysis}

The research was conducted with a total of 86 Hmong American youth (ages 13-18). About 77\% were born in the U.S., while the rest were born in Thailand and immigrated to the U.S. between 1990 and 2004. All of their parents were foreign-born and ranged between 30-60 years of age. Females constituted $52 \%$ and males constituted $48 \%$ of the total respondents. All of the $86 \mathrm{Hmong}$ youth completed the Hmong Youth Adjustment questionnaire, with 50 who filled out the survey during the Hmong Youth Issues conference. The other 36 Hmong youth that completed the survey, were also those who participated in the in-depth interviews from Grant High School. 
The Hmong Youth Adjustment questionnaire was distributed to attendees of a conference for Hmong youth that was focused on addressing issues they face. The questionnaire asked various questions about their school and neighborhood, racial discrimination, friends, parents, values, tastes, and interests to assess how Hmong are adapting in the United States. The purpose was to get a description of the youth who attended the conference and whether their experiences could tell us more about the general Hmong youth population in Sacramento. The conference was organized by students from the Hmong Club at Grant Union High School in Sacramento and by students from Hmong student organizations at Sacramento City College, UC Davis and CSU, Sacramento. They organized a one-day conference, which was held at CSU, Sacramento on April 28, 2007. About $100 \mathrm{Hmong}$ youth between 13 to 18 years of age attended the conference, from high schools in the Sacramento area. The purpose of the conference was to focus on the issues and challenges faced such as suicide, gangs, teen pregnancy, drugs, and problems with school and parents.

The Hmong Youth Adjustment questionnaire and in-depth interviews were conducted among 36 Hmong students from one high school in Sacramento. Data from my survey helped to frame questions for the in-depth interviews. Grant Union High School was one of the largely populated Hmong high schools in Sacramento. In 2008-2009, there were over 2,000 students enrolled at Grant Union High School, with a 30\% Hmong student population. Among the student population at Grant Union High School, 30\% were English learners with 12\% speaking Hmong and $14 \%$ speaking Spanish as their second language. The English learners had a significant number of immigrant students or students who were children of immigrants attending this school. Furthermore, the schools serviced mainly low-income students who were eligible to receive free or reduced lunch. Grant Union High School had $70 \%$ of its student population receiving free or reduced lunch (Grant Union High School, 2009).

By home language, a list of 200 Hmong students and their GPAs (grade point averages) was generated from the $11^{\text {th }}$ and $12^{\text {th }}$ grades for the 2008-2009 academic year. From this list, 40 students were chosen to participate in the interviews and 36 were interviewed. Among the participants, twenty were in the $11^{\text {th }}$ grade and sixteen were in the $12^{\text {th }}$ grade between the ages of 16 and 18. In this group, 18 were boys and 18 girls, with GPAs ranging from 1.0 to a 4.0, were chosen to participate in the in-depth interviews. I also interviewed a total of fifteen teachers, parents, school administrators, and community members to get an overall perspective of the youths' experiences from the larger Sacramento and Hmong community.

As my analysis of the data was guided by grounded theory procedures (Strauss \& Corbin, 1998), I identified major findings such as gender differences in academic performance that were central to the study. These findings then provided categories for more specific topics and themes that led to an in-depth analysis.

\section{Positionality and Methodological Limitations}

I believe my gender (female) and ethnicity (Hmong) immensely helped the girls feel more comfortable and open to share honestly about their life experiences. One girl was even thankful that I had come to her school and asked about her life because she felt there was no one to listen to her troubles. For the boys, it was harder for them to open up to me. Only a handful of the boys I interviewed really went in depth about their life experiences. Overall, I believe that if I had not been Hmong, they may not have shared as much as they did since Hmong boys are usually more 
careful about whom they interact with. My background and experience may have introduced bias into the data collection, analysis, and interpretation. I am second generation, and settled in the U.S. as a young child in the late 1970s. However, my background and understanding of Hmong culture also helped the students, particularly the girls, to feel more comfortable during the interview. Although my research may be informed and shaped by my own positionality, I aim to represent my study participants on their own terms (Ganga \& Scott 2006).

The conference sample was skewed to higher achieving youth. The youth from the high school were selected to achieve variation for gender, age, and GPA. My study was able to tap mainly into a student cohort of higher achieving youth, which does not represent the whole population of second generation Hmong Americans. The participants' viewpoints may not fully represent the total population of Hmong Americans. In addition, the study focused on one group of second generation Hmong Americans at a particular setting, in Sacramento, CA. Therefore, the findings may not be fully applicable to other Hmong Americans in other regions of the country. Although the findings of this study are not generalizable, the data can be used to generate themes and hypotheses for further research and explanation.

\section{Key Findings}

The purpose of this study was to explore the role of gender and culture in the educational achievement of second-generation Hmong American girls and how they respond. This section highlights and discusses key themes that emerged from the data of the study that include gender differences in academic performance, and gender inequality and educational achievement.

\section{Gender Differences in Academic Performance}

The data highlights important gender differences in academic performance among secondgeneration Hmong Americans, specifically the girls as academic achievers. For example, actual and self-reported GPAs, attitudes and aspirations about education, and membership in school organizations show that girls are more school oriented than boys. The actual GPAs of Hmong girls and boys collected from the high school in my study suggest that the girls are outperforming the boys. ${ }^{4}$ Among the 104 students in the $12^{\text {th }}$ grade, only 31 students or $30 \%$ achieved a 3.0 or higher GPA, while 73 students or $70 \%$ achieved a 2.9 or lower GPA. However, when broken down by gender, the actual GPAs for Hmong students in the $12^{\text {th }}$ grade showed that more girls $(50 \%)$ are achieving academic success with a GPA of 3.0 or higher, compared to only $14 \%$ of the boys. The following table shows the differences in academic achievement of the boys and girls in the $12^{\text {th }}$ grade.

Table 1. Gender and academic performance (12 ${ }^{\text {th }}$ graders).

\begin{tabular}{lrc}
\hline GPA & $\begin{array}{c}\text { Boys } \\
(\mathrm{n}=58)\end{array}$ & $\begin{array}{c}\text { Girls } \\
(\mathrm{n}=46)\end{array}$ \\
\hline 3.0 or higher & $(8) 14 \%$ & $(23) 50 \%$ \\
2.9 or lower & $(50) 86 \%$ & $(23) 50 \%$ \\
\hline
\end{tabular}

Source: Grant Union High School, 2008-2009 (N=104) 
Among the ninety-five students in the $11^{\text {th }}$ grade, only 25 students or $26 \%$ achieved a GPA of 3.0 or higher, while 70 students or $74 \%$ achieved a GPA of 2.9 or lower. Similar to the students in the $12^{\text {th }}$ grade, the actual GPAs for Hmong students in the $11^{\text {th }}$ grade showed that more girls $(42 \%)$ are achieving academic success than boys (12\%). The following table shows the differences in academic achievement of the boys and girls in the $11^{\text {th }}$ grade (Table 2 ).

Table 2. Gender and academic performance ( $11^{\text {th }}$ graders).

\begin{tabular}{lrr}
\hline GPA & $\begin{array}{c}\text { Boys } \\
(\mathrm{n}=50)\end{array}$ & $\begin{array}{c}\text { Girls } \\
(\mathrm{n}=45)\end{array}$ \\
\hline 3.0 or higher & $(6) 12 \%$ & $(19) 42 \%$ \\
2.9 or lower & $(44) 88 \%$ & $(26) 58 \%$ \\
\hline
\end{tabular}

Source: Grant Union High School, 2008-2009 (N=95)

Although the data shows that only about one third of the Hmong students at this school in both the $11^{\text {th }}$ and $12^{\text {th }}$ grade levels are achieving a GPA of 3.0 or higher, the GPAs of both groups suggest that the females are outperforming the males. In both grade levels, there are large numbers of males achieving GPAs of 2.9 or lower, while significantly larger numbers of females are achieving GPAs of 3.0 or higher. The actual GPAs of students from this high school with a large population of Hmong students suggest that the girls are outperforming the boys.

Self-reported GPAs from the survey questionnaire further highlight gender disparities in academic performance. Since the GPAs of these youth were self-reported, there may have been a tendency towards exaggeration. Nonetheless, the self-reports point to some interesting patterns. Table 3 shows that $52 \%$ of the boys reported a GPA of 3.0 or higher compared to $80 \%$ of the girls. Additionally, more boys (48\%) reported a GPA of a 2.9 or lower compared to the girls $(20 \%)$. Even with the self-reported GPAs, the patterns show that the girls are outperforming the boys academically.

Table 3. GPA (Self-reported).

\begin{tabular}{lcr}
\hline GPA & $\begin{array}{c}\text { Boys } \\
(\mathrm{n}=42)\end{array}$ & $\begin{array}{c}\text { Girls } \\
(\mathrm{n}=44)\end{array}$ \\
\hline 3.0 or higher & $(22) 52 \%$ & $(35) 80 \%$ \\
2.9 or lower & $(20) 48 \%$ & $(9) 20 \%$ \\
\hline
\end{tabular}

Source: Hmong Youth Adjustment Questionnaire $(\mathrm{n}=86)$

College aspiration also highlights gender differences in academic performance. For instance, Table 4 shows that more girls (89\%) than boys (55\%) believe that college is very important. Additionally, 38\% of the boys compared to $9 \%$ of the girls believe college is fairly important. Overall, more girls than boys believe college is important.

Table 4. College aspiration.

\begin{tabular}{lrr}
\hline $\begin{array}{l}\text { College } \\
\text { Aspiration }\end{array}$ & $\begin{array}{c}\text { Boys } \\
(\mathrm{n}=42)\end{array}$ & $\begin{array}{c}\text { Girls } \\
(\mathrm{n}=44)\end{array}$ \\
\hline Very Important & $(23) 55 \%$ & $(39) 89 \%$ \\
Fairly Important & $(16) 38 \%$ & $(4) 9 \%$ \\
Not Important & $(3) 7 \%$ & $(1) 2 \%$ \\
\hline
\end{tabular}

Source: Hmong Youth Adjustment Questionnaire ( $\mathrm{n}=86)$ 
The difference in academic aspirations among the boys and girls is further supported by Mr. Lor, one of the teachers with a large population of Hmong students. He confirmed that the girls in his classes were more academically motivated and outperformed the boys, "In my classes, the girls do more homework than the boys, and they do it better than the boys. If the boys do homework, they do it only to finish it. However, some boys are very strong."

Membership in school organizations also reveals that girls are more school oriented. I found that more girls had a higher tendency to belong to school organizations than boys. Overall, the majority of girls (84\%) belonged to an organization at school compared to the boys (67\%) (Table 5).

Table 5. School organizational membership.

\begin{tabular}{lcr}
\hline $\begin{array}{l}\text { School Organizational } \\
\text { Membership }\end{array}$ & $\begin{array}{c}\text { Boys } \\
(\mathrm{n}=42)\end{array}$ & $\begin{array}{r}\text { Girls } \\
(\mathrm{n}=44)\end{array}$ \\
\hline Ethnic & $(13) 31 \%$ & $(26) 59 \%$ \\
Non-Ethnic & $(15) 36 \%$ & $(11) 25 \%$ \\
None & $(14) 33 \%$ & $(7) 16 \%$
\end{tabular}

Source: Hmong Youth Adjustment Questionnaire $(\mathrm{n}=86)$

Michelle, who was 16 years of age, explained how her membership in student organizations helped with her academic success:

I was involved with the Renaissance Program, Hmong Women's Circle Program, MESA, FNL, Hmong Youth Conference, and tutoring with the Big, Little Sib Program. The clubs got me involved in school and motivated me to do well in school. I learned a lot about leadership and working with others. It also helped me connect with the community. These programs helped me with my grades because I was motivated to be at school.

Also, more girls (59\%) were involved in ethnic organizations such as a Hmong club, compared to the boys (31\%). Shoua, a fifteen year old, explained that she got involved in the Hmong club at her school because it helped her with her problems at home:

My friends in Hmong club really love and support me. I have a lot of family problems at home and Hmong club listens to me and provides me with advice. They also did a surprise birthday party for me this year because they know I've had a tough time this year. It was the first time in life that I was happy on my birthday. They bought me presents and a cake. All my friends were there and I was so happy.

Similarly, Ngo (2015) found in her study with Hmong American high school students in the Midwest that the Hmong club provided Hmong students with a place of belonging or "home" that helped to foster their identities within a restrictive political and cultural space. Ethnic organizations such as the Hmong club provide a place of belonging, but specifically serve as a source of support for the girls.

These findings highlight important gender differences in the educational trends of Hmong Americans. In a recent analysis of census data from 1990 to 2010, Xiong (2012) found that general trends in educational attainment among Hmong Americans shows gender differences in certain educational outcomes including college attendance, high school drop out rates and college degrees. 
These gender differences highlight that Hmong females are catching up with Hmong males, given that in 1990 males had higher educational attainment (United States Census Bureau, 1990). Additionally, these gender differences suggest the females may even surpass the males by the census data of 2020. The existing data from the Census highlights some important distinctions by gender in the educational attainment of Hmong Americans. However, more data and explanation are needed to understand the educational trends and what they mean (Xiong 2012). Additionally, Lee $(1997,2005)$ observed this trend with her studies on Hmong female students in high school and college. Possible explanations for these outcomes may be found through the experiences of Hmong girls.

\section{Gender Inequality and Educational Achievement}

The girls in the study attested to some form of gender inequality in Hmong culture that provided them with less privilege, reflected their low self-worth, and resulted in more discipline than the boys. Yang at sixteen years of age, talked about not being able to enjoy the same privileges as her brothers in the home:

I have to do everything from scratch while the boys get everything done for them. For example, I have to cook from scratch to eat while the boys just come and eat. I'm the only girl left in the house and it is a lot for me. I mop the floors, sweep, wash dishes, and wash the stove. My brothers don't get to do the chores. They just get to play games. Two out of three brothers don't go to school. The other two goes to work but after work, they get to come home, relax and play games.

Furthermore, the girls expressed low self-worth due to gender norms and inequality within the Hmong culture that places a higher value on the sons. Mary, a fifteen year old, spoke of her feelings:

My parents also told me that I'm just a girl and get married and leave the family. This made me feel like I'm not as valuable as him. It made me feel like I'm just a girl and I can't really do anything. My brother got married when he was fifteen. He is the son of the house and no matter what he does he will always be favored. My parents will always accept him no matter what.

Additionally, Mai Yia, a sixteen year old, explained that her academic success is not as highly valued as a son's:

In my family, no one actually finished college and I want to do that. Sometimes I think about why I should do that because I'm a girl. Onetime, I heard my parents agree with my uncle about how one of his daughters did get a college degree but it doesn't mean much because she is only a girl. It made me feel sad that my parents really feel that way about girls.

The girls also discussed how they received more punishment and discipline by the parents. Jenny, a seventeen year old, expressed: 
My brothers are still childish and just play games. My mom doesn't say anything to them. She's the main person who pays the bills and she should say something to my brothers because they are over eighteen. My brotheris over eighteen and doesn't work and just play games. He goes to school but doesn't take it seriously. Whenever my sister and I do something wrong or just wake up late, we get yelled at.

Similarly, Mai described how she was disciplined differently for making the same choices as her brother:

As we were growing up, my brother would always go out. When he came home they would not say anything to him but for me, my parents would always yell at me. I thought it was really unfair. My parents were really strict on me. My parents treated my brother and me differently.

These findings reflect the study participants' perception and adoption of the personal freedom and greater gender equality offered by U.S. cultural norms that are more favorable to women (Donnelly, 1994; Lee, 1997). While children of immigrants adopt mainstream images of the American family and culture as the norm, they perceive the Asian family and ethnic culture as deficient (Pyke, 2000). Thus, the American family and Western culture are normalized and serve as the ideological template for which they ascribe and measure their negative experiences in the Asian family and ethnic culture. For instance, Pyke (2000) found that the children of immigrants in her study adopted mainstream American values that included preference for parents who provided more freedom, being less strict, more liberal and open-minded, less traditional, and more emotionally expressive and affectionate. Similarly, the girls in this study equated greater personal freedom and gender equality with mainstream American culture, as they rejected and expressed their discontent of the gender norms within Hmong culture. The girls interpreted and perceived their gender inequalities in the Hmong culture against a normalized ideology of mainstream American culture (Pyke, 2000).

As the girls perceive and equate greater gender equality with the American family and mainstream culture, they challenge the gender norms of Hmong culture through education. For instance, Hmong girls expressed using education to break the barriers of gender inequality within the Hmong culture. Chong, who was fifteen years of age, explained how she chose to excel in school to escape the cultural restraints at home:

I'm really into my future and my education. My motivation to do well in school comes from having to fight for my happiness. It's my future and my education that will get me my happiness and allow me to love who I want. I tell my mom that when I turn eighteen I will get a job and be out of the house. I will work and go to school to help myself because right now I'm suffocating from having to live with my parents. I'll just keep going and fighting. When I turn eighteen, I will take control of my own life.

Amy, a sixteen year old, also expressed her motivation for academic success was driven by the gender inequality of the higher worth of boys:

The reason why I am so motivated in school and education is probably because of my parents. They were very traditional and favored the boys over the girls. I grew up in the 
family thinking that I am not as valuable as my brother. My brother had everything his way and I had to have everything my parents' way. I wanted to be better than him by doing good in school and making my parents proud of me. I've been so used to my parents saying that guys are better than girls. But, I feel that even though I'm a daughter but I can do as much or more than my brothers for my parents.

As the girls perceived and equated greater gender equality and personal freedom with American mainstream culture, they challenged gender norms within Hmong culture through educational achievement. In her study with Hmong American high school students in the Midwest, Lee (2005) found that traditional girls who accepted and followed the norms and practices of the Hmong culture perceived gender equality through education which they believed provided the economic freedom to escape the gender norms of Hmong culture. Similarly, the girls in this study perceived and adopted greater independence in mainstream America, which could be achieved through education.

\section{Discussion}

The theme of gender inequality was shared among the majority of second-generation Hmong American girls. For instance, the girls found discontent with the privileges boys enjoyed in the home and the higher value placed on sons. Hmong American girls interpret the gender norms in their ethnic culture as static and innately oppressive of women against the narrative of gender equality in White-dominated mainstream. Consequently, the girls reject their ethnicity and adopt White standards of gender through education. For example, some girls chose to excel in school because they believed educational achievement would gain them access into mainstream American culture, and ultimately gender egalitarianism. While the girls' perceive and equate White femininity and mainstream American culture as more egalitarian, whiteness is normalized as favorable and accepting, and Asian femininity and ethnic culture are constructed as lacking and deficient, reinforcing and reproducing the subordination of Asian femininity and White dominance (Pyke \& Johnson, 2003). This serves as a proassimilation function that reinforces White dominance by suggesting Hmong American girls will find gender equality with White standards of gender. Furthermore, assimilation normalizes integration in the American mainstream as a natural process that is achievable through hard work and individual merit. The assimilation perspective downplays and fails to recognize the racial element of immigration. Saenz and Douglas (2015) argue that the assimilation paradigm reflects the experiences of European immigrants and does not capture the experiences of racially and ethnically diverse immigrants of post 1965. Unlike previous European immigrants who were treated as ethnic immigrants, post 1965 immigrants are racialized immigrants and treated as non-White, and are unable to fully integrate or achieve U.S. citizenship (Saenz \& Douglas, 2015; Volpp, 2010).

The experiences of second-generation Hmong American girls and educational achievement are more complicated than explaining culture as deficient or advantageous for minority student achievement. These discursive practices racialize achievement as Asian American and failure as African American (Caplan et al, 1991; Sue \& Okazaki, 1990; Zhou \& Bankston, 1998). The perspectives of the Hmong American girls in this study show that their educational choices are largely informed by messages about whiteness that convey success as assimilation into the American mainstream and gender equality as White femininity. Ultimately, their pursuit of 
educational success is driven by the racialized and gendered processes that "other" and exclude Asian ethnic cultures and femininity as deficient and lacking, while normalizing mainstream American culture and White femininity as favorable and egalitarian (Pyke \& Johnson, 2003). Whiteness is stabilized as superior, while Asian American remains racially ambiguous as neither Black nor White but only serve as cultural determinants for success and failure (Ancheta, 2010; Kim, 1999).

Education plays an important role in shaping gender norms in Hmong culture and challenges the portrayal of Hmong culture as static and resistant to change (Faderman, 1998; Fadiman, 1997; Mote, 2004; Tapp, 1998). More specifically, gender differences in educational attainment among Hmong Americans reveal the fluidity and dynamics of Hmong culture. Hmong American women negotiate gender norms in their ethnic culture with educational achievement and are therefore redefining and producing new meanings and boundaries for Hmong culture. Along with other scholars, I argue that Hmong American women are active participants of cultural change through their resistance, negotiation, and recreation of gender norms (Lee, 1997; Ngo, 2002; Vang, et al., 2016). However, my analysis of the largely accepted and adopted White standards of gender norms among second-generation Hmong American girls reveal the dominance of whiteness and illustrate the power of hegemonic femininity in promoting internalized oppression (Lee, 2005; Pyke \& Johnson, 2003). The findings illustrate that the educational choices of Hmong American girls are influenced by discourse that racially subordinates Asian femininity and ethnic cultures.

\section{Conclusion}

In this article, I extend the research on minority student achievement and immigrant incorporation that construct culture as a deficiency or advantage for academic success. I examined the ways second-generation Hmong American girls interpret and respond to gender norms through education. As evidence of their assimilation, second-generation Hmong girls adopt White standards of gender and equate gender egalitarianism with White femininity and mainstream American culture, which causes them to reject their ethnic culture and identity (Pyke \& Johnson, 2003). This article highlights how the resistance of gender oppression among respondents draws ideologically on a racial discourse that reinforces White dominance.

A racialized examination of gender is central to understanding the educational choices of second-generation Hmong American girls. The discursive practices in education scholarship racialize Asian Americans outside the boundaries of the American citizen along lines of cultural difference, while normalizing mainstream American culture or White middle-class America as dominant (Ancheta, 2010; Kim, 1999; Volpp, 2010). Volpp (2010) explains that the racial marker of "excessive culture," emphasized as either positive (model minority) or negative (foreign or culturally different), places Asian Americans outside the boundaries of what is considered the American citizen. Additionally, the immigration scholarship promotes a proassimilationist perspective that constructs Asian ethnic cultures as static, monolithic sites of male dominance and female submissiveness and normalizes White-dominated mainstream as standard (Pyke \& Johnson, 2003). Those that deviate from this norm are blamed for their own plight.

The study allowed for rich data that described the experiences of second-generation Hmong American students. The findings of this study are not generalizable. The sample mainly a student cohort of higher achieving youth in one metropolitan area and is not representative of young Hmong Americans in general. The sample consisted of young Hmong American students who 
average similar GPAs, are of similar age, are mostly U.S. born with immigrant parents, and who share similar values such as education and cultural tastes and interests. Their experiences may not fully represent the general Hmong youth population in Sacramento or the U.S. Despite these limitations, I can still draw some important theoretical conclusions from the data. If the findings were prevalent among the higher achieving Hmong youth, it is a strong indicator the less successful youth may be experiencing these issues as well.

There is need for further studies that show how racial discourse impacts minority student achievement and immigrant incorporation. As scholars, it is critical that we critique and identify the racist undertones of arguments based on cultural differences that are prominent in explaining the educational experiences of racialized groups and immigrants. We must develop and employ analytical frameworks that allow us to capture and show the impact of gender, race, ethnicity, nationality, sexuality, class, and legal status on the lives of immigrants and minorities. We should resist disciplinary practices that ghettoize cultures and groups that fail to achieve whiteness.

Policy makers should implement policy that does not ignore or punish groups that do not fit the standard of whiteness. The experiences of the Hmong girls show that second-generation Hmong Americans do not have a space to freely be themselves. The option to be ethnically "Hmong" constructs them as a model minority or a deviant in education, as their racialization is equated with cultural difference. Whiteness is normalized and saturated in the messages they receive about success and gender equality (Lee, 2005). Thus, their resistance of gender oppression in their ethnic culture draws ideologically on a racial discourse that reinforces White dominance. The educational system of K-12 needs to help raise the consciousness of students through critical dialogues of whiteness and the systems that normalize structural inequalities. Schools should provide a space for students to be critical and conscious of whiteness or White dominance. Educators need to provide critical pedagogy and resources that go beyond cultural competency (Ladson-Billings, 1992). For instance, policies that reduce race and racism to cultural differences and ethnic diversity invoke a multiculturalist framework that perpetuates neoliberalism and colorblind racism (Omi \& Winant, 2015; Bonilla Silva, 2014).

\section{Notes}

1. Second generation Hmong Americans, consist of native-born children of foreign parents or foreign-born children who were brought to the United States before adolescence (Portes \& Rumbaut, 2001).

2. Since the mid-1960s, immigrants have mainly come from Asia, Latin American, and the Caribbean. They consisted of both low and high human capital. The 2010 Census estimates that almost $13 \%$ of the total U.S. population is foreign-born. It is estimated that if the "new" immigrants from these countries continue to account for the larger share of immigration, the population of the U.S. acquire an additional 80 million as a direct or indirect consequence by 2050 (Smith \& Edmonston, 1997, p. 95). Due to the diversity and growing numbers of post 1965 immigrants and their offspring, their ability to assimilate and be incorporated into American society has become a central issue for academic discussion and policy debate. Scholars have advocated for examining the success or failures of the "new second generation" as they are better indicators of how contemporary immigrants are faring and how subsequent generations will succeed (Portes \& Rumbaut, 2001; Zhou \& Bankston, 1998).

3. Of the total U.S. Hmong population, $60 \%$ are American born. The median age of the Hmong population is 20 years of age, with $42 \%$ of this population is under the age of 18 , compared to $24 \%$ of the U.S. population that is under the age of 18. Most of the 18 and under are second generation because the flow of Hmong refugees stopped in the early 1990s. However, in 2004 and 2005 the latest wave of Hmong refugees resettled 
from Thailand. More than $60 \%$ of the 15,000 new refugees who came between 2004 and 2005 are under the age of 18 . These numbers indicate that Hmong Americans are a relatively young population with a significant American-born second generation.

4. These grade point averages (GPAs) only reflect the Hmong girls and boys from the high school chosen for this study (Grant High School). These GPAs do not represent those youth who attended the Hmong youth issues conference. A list was generated by home language with $104 \mathrm{Hmong}$ students in the $12^{\text {th }}$ grade and 95 Hmong students in the $11^{\text {th }}$ grade for academic year 2008-2009.

\section{References}

Ancheta, A.N., (2010). Neither Black nor White. In J. Y. Shen Wu \& T. C. Chen (Eds.), Asian American studies now: A critical reader (pp. 21-34). New Jersey, NJ: Rutgers University Press.

Bonilla-Silva, E. (2014). Racism without racists: Colorblind racism and the persistence of racial inequality in America. Maryland, MD: Rowman \& Littlefield Publishers, Inc.

Caplan, N., Choy, M. H., \& Whitmore, J. K. (1991). Children of the boat people: A study of educational success. Ann Arbor, MI: The University of Michigan Press.

Cha, D. (2013). Women in the Hmong diaspora. In M. E. Pfeifer, M. Chiu, \& K. Yang (Eds.), Diversity in diaspora: Hmong Americans in the twenty-first century (pp. 165-187). Honolulu, HI: University of Hawaii Press.

Chiang, A., Fisher, J., Collins, W., \& Ting, Marie. (2015). Mislabeled: The challenge of academic capital formation for Hmong American high school students in an urban setting. Journal of Southeast Asian American Education and Advancement, 10(1), 1-31.

Collins, P. H., \& Bilge, S. (2016). Intersectionality. Malden, MA: Polity Press.

Donnelly, N. (1994). Changing lives of refugee Hmong women. Seattle, WA: University of Washington Press.

Faderman, L. (1998). I begin my life all over again: The Hmong and the American immigrant experience. Boston, MA: Beacon Press.

Fadiman, A. (1997). The spirit catches you and you fall down: A Hmong child, her American doctors, and the collision of two cultures. New York, NY: Farrar, Straus and Giroux.

Ganga, D., \& Scott, S. (2006). Cultural "insiders" and the issue of positionality in qualitative migration research: Moving "across" and moving "along" researcher-participant divides. Forum: Qualitative Social Research, 7(3), 1-12.

Gibson, M. A. (1988). Accommodation without assimilation: Sikh immigrants in an American high school. Ithaca, NY: Cornell University Press.

Grant Union High School. (2009). Student enrollment. Office of Registrar. Sacramento, CA.

Hondagneu-Sotelo, P. (1994). Gendered transitions: Mexican experiences of immigration. Berkeley, CA: University of California Press.

Keown-Bomar, J., \& Vang, K. (2016). Hmong women, family assets, and community cultural wealth. In C. Y. Vang, F. Nibbs, \& M. Vang (Eds.), Claiming place: On the agency of Hmong women (pp. 117-143). Minneapolis, MN: University of Minnesota Press.

Kibria, N. (1993). Family tightrope: The changing lives of Vietnamese Americans. Princeton, NJ: Princeton University Press. 
Kim, C. J. (1999). The racial triangulation of Asian Americans. Politics and Society, 27(1), 105-138.

Ladson-Billings, G. (1992). Culturally relevant teaching: The key to making multicultural education work. In C. A. Grant (Ed.), Research and multicultural education (pp. 106121). London, UK: Falmer Press.

Lee, S. J. (1997). The road to college: Hmong American women's pursuit of higher education. Harvard Educational Review, 67(4), 803-827.

Lee, S. J. (2005). Up against whiteness: Race, school, and immigrant youth. New York, NY: Teachers College Press.

Lee, S. J. (2007). The "good" news and the "bad" news: The "Americanization of Hmong girls.” In B. J. Ross Leadbeater \& N. Way (Eds.), Urban girls revisited: Building strengths (pp. 202-217). New York, NY: New York University Press.

Lo, B. (2013). The second generation story of Hmong Americans. (Doctoral dissertation). Retrieved from Dissertation Abstracts International. (Order No. 3616375)

Loescher, G., \& Scanlan, J. A. (1986). Calculated kindness: Refugees and America's half-open door. New York, NY: Free Press; London, UK: Collier Macmillan.

Menjivar, C. (2000). Fragmented ties: Salvadoran immigrant networks in America. Berkeley, CA: University of California Press.

Moua, L., \& Riggs, J. (2012). Navigating multiple worlds: A qualitative study of the lived experiences of Hmong women leaders. Journal of Southeast Asian American Education and Advancement, 7(1), 1-23.

Mote, S. M. (2004). Hmong and American: Stories of transition to a strange land. London, UK: McFarland \& Company, Inc.

Ngo, B. (2002). Contesting "culture": The perspectives of Hmong American female students on early marriage. Anthropology and Education Quarterly, 33(2), 163-188.

Ngo, B. (2015). Hmong culture club as a place of belonging: The cultivation of Hmong students' cultural and political identities. Journal of Southeast Asian American Education and Advancement, 10(2), 1-16.

Ngo, B., \& Lee, S. (2007). Complicating the image of model minority success: A review of southeast Asian American education. Review of Educational Research, 77(4), 415-453.

Omi, M., \& Winant, H. (2015). Racial formation in the United States. ( $3^{\text {rd }}$ ed.). New York, NY: Routledge.

Pessar, P. R. (1999). Engendering migration studies. The case of new immigrants in the United States. American Behavioral Scientist, 42(4), 577-600.

Portes, A., \& Rumbaut, R. G. (2001). Legacies: The story of the immigrant second generation. Berkeley, CA: University of California Press.

Pyke, K. D. (2000). "The normal American family" as an interpretive structure of family life among grown children of Korean and Vietanmese immigrants. Journal of Marriage and the Family, 62, 240-255.

Pyke, K. D., \& Johnson, D. L. (2003). Asian American women and racialized femininities: "Doing" gender across cultural worlds. Gender \& Society, 17(1), 33-53.

Reder, S. (1986). The Hmong resettlement study: A symposium. In G. L. Hendricks, B. T. Downing, \& A. S. Deinard (Eds.), The Hmong in transition (pp.175-178). New York, NY: The Center for Migration Studies of New York, Inc.

Rutledge, P. J. (1992). The Vietnamese experience in America. Bloomington, IN: Indiana University Press. 
Saenz, R. \& Douglas, K. M. (2015). A call for the racialization of immigration studies: On the transition of ethnic immigrants to racialized immigrants. Sociology of Race and Ethnicity, 1(1), 166-180.

Smith, J. P., \& Edmonston, B. (1997). The new Americans: Economic, demographic, and fiscal effects of immigration. Washington, DC: National Academy Press.

Stodghill, R., \& Bower, A. (2002, August 25). "Welcome to America's most diverse city". Time Magazine, 1-3.

Strand, P. J., \& Jones, W. (1985). Indochinese refugees in America: Problems of adaptation and assimilation. Durham, NC: Duke University Press.

Strauss, A. \& Corbin, J. (1998). Basics of qualitative research: Techniques and procedures for grounded theory. ( $2^{\text {nd }}$ ed). Thousand Oaks, CA: Sage Publications.

Sue, S., \& Okazaki, S. (1990). The Asian-American educational achievement: A phenomenon in search of an explanation. American Psychologist, 45, 913-920.

Tapp, N. (1998). The reformation of culture: Hmong refugees from Laos. Journal of Refugee Studies, 1(1), 20-37.

Trueba, H., Jacobs, L., \& Kirton, E. (1990). Cultural conflict and adaptation: The case of Hmong children in American society. New York, NY: Falmer. United States Census Bureau. (2009). Table S0201. Selected Population Profile in the United States. 2007-2009 American Community Survey 3-Year Estimates. Retrieved From https://factfinder.census.gov/faces/tableservices/jsf/pages/productview.xhtml?pid=ACS_ 09_3YR_S0201\&prodType=table

United States Bureau of the Census (1990). 1990 Census of population: General population characteristics of the United States. Bureau of the Census: Washington, DC.

United States Bureau of the Census (2010). 2010 Census of population: General population characteristics of the United States. Bureau of the Census: Washington, DC.

Vang, C. Y. (2008). Hmong in Minnesota. St. Paul, MN: Minnesota Historical Society Press.

Vang, C. Y., Nibbs, F., \& Vang, M. (2016). Claiming place: On the agency of Hmong women. Minneapolis, MN: University of Minnesota Press.

Vang, H. (2004). Hmong American women's educational attainment: Implications for Hmong American women and men. In Hmong National Development Inc. \& Hmong Cultural and Resource Center (Eds.), Hmong 2000 Census Publication: Data and Analysis (pp. 23-25). Washington, DC: Hmong National Development, Inc.

Volpp, L. (2010). Excesses of culture: On Asian American citizenship and identity. Asian American Law Journal, 17(1), 63-81.

Walker-Moffat, W. (1995). The other side of the Asian American success story. San Francisco, CA: Jossey-Bass, Inc.

Xiong, Y. S. (2012). Hmong Americans' educational attainment: Recent changes and remaining challenges. Hmong Studies Journal, 13(2), 1-18.

Yang, K. (2013). The American experience of the Hmong. In M. E. Pfeifer, M. Chiu, \& K. Yang (Eds.), Diversity in diaspora: Hmong Americans in the twenty-first century (pp. 3-53). Honolulu, HI: University of Hawaii Press.

Zhou, M., \& Bankston, C. L. III. (1998). Growing up American: How Vietnamese children adapt to life in the United States. New York, NY: Russell Sage Foundation.

Zhou, M., \& Lee, J. (2015). The Asian American achievement paradox. New York, NY: Russell Sage Foundation. 


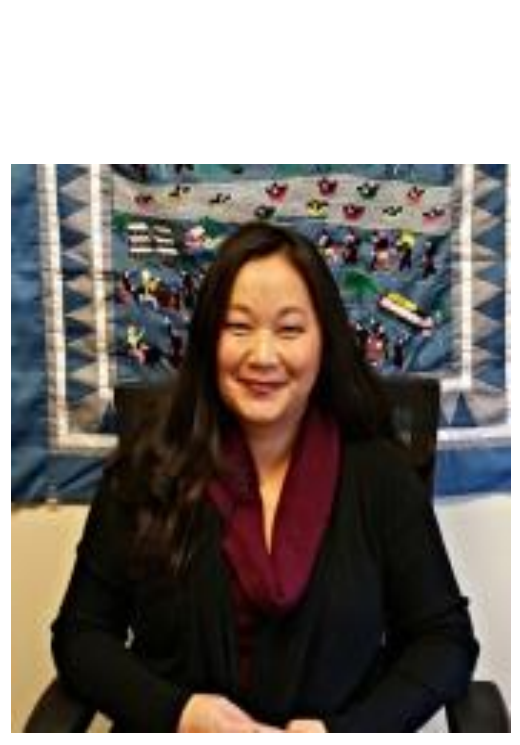

About the Author

Dr. Bao Lo is Assistant Professor and Director of the Ethnic Studies Program at California State University, Stanislaus. She received her Ph.D. from the Department of Ethnic Studies at the University of California, Berkeley. Her research interests include U.S. immigration with a focus on the second generation (children of post 1965 immigrants), race and ethnicity, gender, and Asian Americans, with a specialization in Southeast Asian Americans and Hmong Americans. Dr. Lo is a secondgeneration Hmong American and focuses her research on Hmong Americans in the central valley of California. 


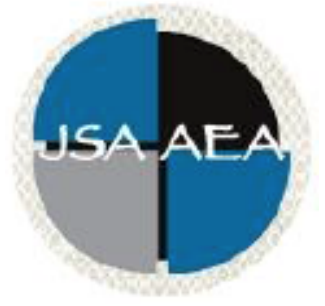

Vol.12 Iss.1 (2017)

\title{
Journal of Southeast Asian American Education and Advancement
}

\author{
WwW.JSAAEA.org
}

\section{Editor}

Dr. Wayne E. Wright

Purdue University

Associate Editors

Dr. Chhany Sak-Humphry

University of Hawaii at Manoa

Dr. Phitsamay Sychitkokhong Uy

University of Massachusetts, Lowell

\author{
Book Review Editor \\ Dr. Vichet Chhuon \\ University of Minnesota \\ Creative Works Editor \\ Bryan Thao Worra \\ Lao Assistance Center \\ Journal Manager \\ Fang Gao \\ Purdue University
}

\section{Editorial Review Board}

Dr. Steve Arounsack

California State University, Stanislaus

Dr. Sovicheth Boun

Salem State University

Dr. Virak Chan

Purdue University
Dr. Carl L. Bankston III

Tulane University

Dr. Phala Chea

Lowell Puclic Schools

Dr. George Chigas

University of Massachusetts, Lowell 


\author{
Dr. Loan Dao \\ University of Massachusetts Boston \\ Dr. Changming Duan \\ University of Missouri-Kansas City \\ Dr. Sothy Eng \\ Lehigh University \\ Dr. Vincent K. Her \\ University of Wisconsin, Eau Claire \\ Dr. Peter Nien-Chu Kiang \\ University of Massachusetts, Boston \\ Dr. Kevin K. Kumashiro \\ University of Illinois, Chicago \\ Dr. Ha Lam \\ Eastern Mennonite University \\ Dr. Jonathan H. X. Lee \\ San Francisco State University \\ Dr. Monirith Ly \\ Royal University of Phnom Penh \\ Dr. Bic Ngo \\ University of Minnesota \\ Dr. Leakhena Nou \\ California State University, Long Beach \\ Dr. Mark Pfeifer \\ SUNY Institute of Technology \\ Dr. Loan T. Phan \\ University of New Hampshire \\ Dr. Karen Quintiliani \\ California State University, Long Beach \\ Dr. Angela Reyes \\ Hunter College \\ The City University of New York \\ Dr. Fay Shin \\ California State University, Long Beach \\ Dr. Christine Su \\ College of San Mateo \\ Dr. Alisia Tran \\ Arizona State University \\ Dr. Khatharya Um \\ University of California, Berkeley \\ Dr. Kim Tran \\ University of California, Los Angeles, \\ Glendale Community College \\ Dr. Molly Wiebie \\ The University of Texas at Austin
}

Dr. Hien Duc Do

San Hose State University

Dr. Sophal Ear

Occidental College

Dr. Jeremy Hein

University of Wisconsin, Eau Claire

Dr. Nancy H. Hornberger

University of Pennsylvania

Dr. Peter Tan Keo

New York University

Dr. Yvonne Kwan

San Jose State University

Dr. Ravy Lao

California State University, Los Angeles

Dr. Stacey Lee

University of Wisconsin, Madison

Dr. Sue Needham

California State University, Dominguez Hills

Dr. Max Niedzwiecki

Daylight Consulting Group

Dr. Clara Park

California State University, Northridge

Dr. Giang Pham

University of Massachusetts Amherst

Dr. Malaphone Phommasa

University of Clifornia Santa Barbara

Dr. Kalyani Rai

University of Wisconsin-Milwaukee

Dr. Cathy J. Schlund-Vials

University of Connecticut, Storrs

Dr. Nancy J. Smith-Hefner

Boston University

Dr. Yer J. Thao

Portland State University

Dr. Monica M. Trieu

Purdue University

Dr. Silvy Un

Saint Paul Public Schools

Dr. Linda Trinh Vo

University of California, Irvine

Dr. Yang Sao Xiong

The University of Wisconsin-Madison

Dr. Zha Blong Xiong

University of Minnesota 


\section{Doctoral Student Editorial Review Board}

\author{
Linh Dang \\ University of Rochester \\ My-Lan Huynh \\ California State University East Bay \\ Hoa Nha Nguyen \\ Boston College \\ Thien-Huong Ninh \\ University of Southern California \\ Krissyvan Truong \\ Claremont Graduate University \\ Melissa Vang \\ San Diego State University \\ Claremont Graduate University \\ Anna H. Yang \\ University of Georgia
}

\author{
Annie BichLoan Duong \\ San Joaquin County Office of Education \\ Dung Minh Mao \\ University of Minnesota \\ Khoi Nguyen \\ George Mason University \\ Linda Marie Pheng \\ University of Wisconsin-Madison \\ Mai Vang \\ University of Massachusetts Boston \\ Soua Xiong \\ San Diego State University \\ Claremont Graduate University
}

